\title{
Ethical Aspects of the Conscience Clause in Polish Medical Law $^{2}$
}

\begin{abstract}
In Polish medical law, the conscience clause is understood as both a moral and legal norm which gives consent to selected medical professions (doctors, nurses, midwives, and laboratory technicians) to withdraw certain activities due to ethical objections.

The explanation given for the conscience clause is not sufficient. There is no detailed information on the difference between compulsory and authorized benefits and the conditions for resignation from medical treatment. These problems not only lead to interpretational errors, but also to the abuse of law. Medical attorneys, among others, Andrzej Zoll, Mirosław Nesterowicz, Leszek Bosek and Eleonora Zielińska, present different opinions on the understanding of refusal to perform health care services by health care workers, and the lack of agreement leads to conflicts.

In this article, I compare the views of ethicists and lawyers on the conscience clause. I present differences in the interpretation of medical law, and to all considerations I add my own opinion.
\end{abstract}

\section{Keywords:}

conscience clause, abortion, doctor, patient's rights, medical deontology, ethics

1 Department of Social Sciences and Humanities, Faculty of Health Sciences, Poznań University of Medical Sciences, Poznań, Poland.

E-MAIL: justynaczekajewska@gmail.com ORCID: 0000-0003-2833-8815

2 The article is an enlarged version of the paper, with the same title, delivered at the international conference: Historische Aspekte der Gesundheitsvorsorge und Krankheitsprävention in Deutschland und Polen, Hamburg, 12-14.07.2017.The article was written as part of a research project titled The right to freedom of belief and the professional responsibility of medical workers from research grant awarded by Faculty of Health Sciences, Poznań University of Medical Sciences (502-14-44065120-10593). 


\section{INTRODUCTION}

During ethics classes I ask students whether they think the conscience clause should be both a legal and ethical norm? For most people, I get the answer that it is only an ethical matter. According to students, anyone who has made the decision to study medicine should be aware of the actions that can cause moral conflict. One of the participants said, if a gynecologist does not want to perform an abortion for religious or ethical reasons, he should have not become a doctor ${ }^{3}$.

Laconic statements of students prompted me to consider further. My attention was drawn to the fact that some seminarians have difficulty distinguishing between ethical and legal norms and often think that legal norms take precedence over ethical standards. In other words, that they are more important. In their opinion, if the conscience clause is to be used as a legal norm, doctors may routinely use it, which would lead to legal proceedings involving health professionals (Nesterowicz \& Karczewska-Kamińska, 2014, p. 127) ${ }^{4}$.

As a result, for many students, the fear of losing a job is more important than doing the medical work in harmony with one's own conscience. In their opinion, conscience can be drowned or anesthetized but work will not be restored.

The question is whether we can agree with this argument and recognize that the conscience clause should not have its own record in the law?

Before I answer the question, I want to point out that not every ethical norm is a legal norm, just as not every legal norm is assigned to a specific moral system. However, according to the definition of Galewicz, the clause of conscience is understood in Polish medical law as both an ethical norm and a legal norm (Galewicz, 2012, pp. 137-141; Czekajewska, 2016, pp. 33-46). According to the scholar, freedom of belief is one of human basic values. The right to own worldview is not a privilege, but "basic value" that shapes humanity. Respect for the freedom of conscience stems from respect for the human person and their own dignity. Other rights such as the right to life or the right to property are also innate and no one, no man or institution, can ever deprive anyone of these rights.

3 Student's answer about the conscience clause. The talk was held at a seminar on the subject: Ethical Medicine with Deontology, in 2017.

4 "According to the Helsinki Foundation for Human Rights, which has entered the proceedings as a third party, the conscience clause in Poland is often abused. In addition to using it by some physicians who do not fulfill the obligation to indicate the real possibility of obtaining a given benefit from another doctor or other healing entity, the whole of the therapeutics are also public. Although this is a well-known problem, no effective mechanism is in place to ensure compliance with the right to abortion". 
Various international documents confirm this piece of information, for example The Universal Declaration of Human Rights, the European Convention on Human Rights, and the International Covenant on Civil and Political Rights (The Universal Declaration of Human Rights, 1948; The European Convention on Human Rights, 1950; The International Covenant on Civil and Political Rights, 1966; Resolution 1763 on the Right to Conscientious Objection in Lawful Medical Care, 20105; Zoll, 2014, p. 78) ${ }^{6}$. It has been also noted by Włodzimierz Galewicz, lawyers: Andrzej Zoll, Oktawian Nawrot, Leszek Bosek, Mirosław Nesterowicz, and Natalia Karczewska-Kamińska. Everyone claims that every human being has the right to his or her own world view and should be allowed to freely express his or her personal religious and ethical convictions. States with a democratic system have to protect the freedom of conscience of their citizens and should not use mechanisms of oppression. Discrimination against faith should be forbidden.

The views of listed ethicists and lawyers are legitimate as they focus on ethical pluralism. Nobody lives in a country with only one system of values. The religious and ethical views of citizens may change, but the task of the jurisdiction in the rule of law is not to determine the worldview of society nor to impose it, but to preserve it (Zoll, 2014, p. 78). Legal regulations should safeguard the freedom of conscience, should guard the private beliefs of the citizen, and not force them to accept views incompatible with personal thoughts.

In this way we see the difference between two sets of norms: ethical and legal. There are many systems of normative ethics and every person has the right to choose one of them. One can agree with the assumptions of personalistic ethics and reject the views of utilitarianists, or solve ethical conflicts according to the assumptions of situational ethics and be opponents of moral absolutism. In any case, it should be assumed that ethical standards should be chosen by citizens rather than imposed by the state.

5 "No person, hospital or institution shall be coerced, held liable or discriminated against in any manner because of a refusal to perform, accommodate, assist or submit to an abortion, the performance of a human miscarriage, or euthanasia or any act which could cause the death of a human fetus or embryo, for any reason".

6 "Freedom of belief and freedom of conscience and the person's ethical approval, resulting from the accepted worldview, are entirely outside the jurisdiction of the democratic state of law, and only the state authority is obliged to safeguard and guarantee this freedom. It is also done by the Constitution of the Republic of Poland in several articles from which Article 31, Article 35 (2), Article 47, Article 48, Article 53. Also Poland's binding norm of international law confirms this fundamental right. This is done primarily by the European Convention on Human Rights and Fundamental Freedoms, stating in Article 9 Section 1 and the International Covenant on Civil and Political Rights in Article 18”. 
A different thing applies to legal norms. These must be strictly defined and clearly worded, not to leave any doubt to their interpretation. If someone acts contrary to the letter of law and uses legal regulations to protect particular interests, then they should be punished.

Legal sanctions are not intended to limit the freedom of individuals but to protect the freedom of conscience of citizens and to protect them from the abuse of power by various social groups or institutions.

\section{UNCLEAR WORDING OF ARTICLE 39 OF THE ACT ON THE PROFESSIONS OF DOCTOR AND DENTIST}

In Polish medical law, the conscience clause is found in Article 39 of the Act of 5 December 1996 on the Professions of Doctor and Dentist. The law of the physician to refuse to act contrary to their own conscience is subject to considerable controversy. Some doctors, ethicists and lawyers are in a constant debate on changing the content of the law. In their opinion, the present document contains ambiguities. It lacks precise findings, explanations of the terms and terms used, and some people, like Leszek Bosek, believe that its content is incompatible with the Constitution of the Republic of Poland (Bosek, 2014, p. 100)7.

These remarks can be thoroughly understood if you analyze the contents of the act. It states as follows:

A doctor may refrain from performing health services incompatible with his own conscience, subject to Article 30, but is required to indicate the real possibility of obtaining this benefit from another doctor or another health care facility as well as justify it and record it in medical records. A physician who performs his occupation on the basis of an employment or service relationship shall, in addition, be obliged to give advance notice in writing to the supervisor (Act on the Professions of Doctor and Dentist, 1996).

The dispute surrounding the law concerns several important issues:

1. Determining a professional group that has the right to use the conscience clause;

2. Determining compulsory services - analysis of Article 30;

7 "It seems that Article 39 of the Act is inconsistent with Article 53 Paragraph 1 and Article 30 of the Constitution of the Republic of Poland, primarily because it establishes an absolute and categorical obligation to provide services inconsistent with the doctor's conscience in every case, an urgent need, far beyond the need to provide help in a life-threatening or serious health emergency”. 
3. Notifying the patient about the resignation from the medical action;

4. Indicating the doctor who will perform the medical treatment;

5. Notifying the supervisor of the resignation of the medical service.

All the aforementioned issues raise doubts. The vague ambiguity and arbitrary interpretation of this article may be the cause of moral conflicts between the physician and the patient. In order to avoid misunderstandings, it is important to explain precisely the difficulties identified.

\section{WHO DOES THE CONSCIENCE CLAUSE IN POLISH MEDICAL LAW INVOLVE?}

Identifying the appropriate professional groups that have the right to use the conscience clause is a subject of ongoing discussion. The problem is not only to determine who can report ethical objections and have the right to refuse medical services, but also if the collective rights can be used by the public.

Thus, the question is if we should consider whether Article 39 of the Act on the Professions of Doctor and Dentist concerns only selected medical workers such as doctors, nurses and midwives, or also representatives of other medical professions such as pharmacists?

In addition, it is worth rethinking whether only individuals, in other words, individual medical workers have the right to use the conscience clause, or does it also affect institutions such as hospitals?

In order to answer the given questions, it is worth noting that we usually talk about the clause of conscience when it comes to doctors (Zoll, 2014, p. 81). This subject is considered in a narrow scope, and this is because we usually refer to it for abortion. When we discuss other issues such as euthanasia, gender selection, embryo selection, donor organs removal, or experimental research involving people, the issue of freedom of conscience also arises, but practically, it is relevant when discussing abortion (Zoll, 2014, p. 82).

In Polish medical law, it is written that the conscience clause refers exclusively to doctors, nurses and midwives. In addition to Article 39, which was previously mentioned, we also have other documents such as Article 12 Section 2 of the Act on the Professions of Nurses and Midwives, and Standing Committee of Bioethics at the Presidium of the PAN of 12 November 2013.

The content of both documents is as follows: 
The nurse and midwife may refuse to perform a medical order and perform another health service that is incompatible with their conscience or the scope of their qualifications, immediately giving the reason for refusal in writing to the supervisor or the ordering party, unless the circumstances referred to in paragraph 1 (Act on the Professions of Nurses and Midwives, 2011).

According to Polish law, the right to refuse to perform a health service being contrary to one's own conscience is vested only in a physician, a dentist, or a nurse or a midwife. The right to refer to the conscience clause does not include representatives of other medical professions, particularly pharmacists (The Position of the Committee of Bioethics at the Presidium of the Polish Academy of Sciences, 2013).

Polish medical law presumes that only doctors, nurses and midwives can use the conscience clause, and employees of other medical professions cannot. According to Andrzej Zoll and Leszek Bosek, this provision is contrary to the Constitution of the Republic of Poland and should be changed. Lawyers' remarks particularly refer to the content of Article 53 Section 1 of the Constitution of the Republic of Poland, which proclaims that "[any] state guarantees freedom of conscience and religion” (The Constitution of the Republic of Poland of 2 April 1997; Dz.U. Nr 78, poz. 483). According to lawyers, since freedom of conscience concerns every human being, it cannot be claimed that there are privileged groups that this term encompasses. Such an interpretation of the law is not only incompatible with the internal directive of the country but also with international regulations. In addition, in the opinion of scholars, the conscience clause should concern not only every health worker but also collective entities - hospitals.

In my opinion, Andrzej Zoll and Leszek Bosek read freedom of conscience literally. While the Constitution of the Republic of Poland guarantees the right to freedom of belief for all citizens, it does not mean that every man can invoke a clause of conscience. If it was possible, all people would have the right to not perform various activities, and especially professional ones, only because these activities are contrary to their worldview, and such an assumption is absurd because it does not solve moral conflicts, but has an influence on their formation (Nawrot, 2014, p. 115) ${ }^{8}$.

In addition, I find it disturbing to say that the management of hospitals can impose moral convictions on their subordinates. In accordance with Article 31

8 "For example, in Jean Bouessel du Bourg v. France, the European Commission for Human Rights stated that the taxpayer's refusal to pay taxes was due to the fact that the means thus obtained could be spent by the state to finance practices not accepted by the taxpayer such as abortion, cannot be interpreted in terms of the exercise of the right to conscientious objection, because the link between tax evasion and abortion is too weak". 
Section 3 of the Constitution of the Republic of Poland, the restriction of freedom and rights can only take place when the security or public order, the public health and morals or the rights and freedoms of others are threatened (Article 31 Section 3 of the Constitution of the Republic of Poland, 1997). In other situations, it is not acceptable to impose beliefs on others. This entry is understood as follows. Each patient, if he can consciously express his own views, has the right to preach. Regardless of the doctor's personal beliefs, he is obliged to respect the will of the patient. The basic principles of medical ethics such as the right to autonomy or the right to harm (Beauchamp \& Childress, 1996, p. 132) ${ }^{9}$ do not require healthcare professionals to follow the decisions of their patients. Exceptional limitation of these rights occurs when the patient is unconscious or under age. Under such circumstances, the legal guardians generally make the decision for a patient. However, it cannot be ruled out that the decision of family members will be contrary to the doctor's views. A very good example is blood transfusion in people of other denominations, such as Jehovah's Witnesses. If the patient is a child and the parents' decision is - from the doctor's point of view - unfavorable to their health or life, then I believe that according to the Constitution of the Republic of Poland and the Code of Ethics, the doctor has the right to follow their own conscience, i.e., to oppose the will of the parents and to save the patient's life.

The doctor would not be able to do this if the patient was of age and aware. In this situation, the doctor is obliged to respect the patient's opinion even if their decision raises contradictory feelings.

In other cases, I find it unethical and unlawful to say that representatives of institutions such as hospitals have the right to impose their views on employees.

According to the Universal Declaration of Human Rights, everyone has the right to freedom of belief. You cannot create jobs where this principle will not be respected. I cannot imagine that the doctors have to deny their views in order to accept the management of the hospital, and if they do not, they would be forced to leave.

Zielińska and Boratyńska wrote about the abuse of the conscience clause. According to medical professionals: "Conscience clause may concern physicians, not public establishments, which must ensure the realization of patient rights" (Nesterowicz \& Karczewska-Kamińska, 2014, p. 123). Incorrect understanding of the record may lead to the conclusion that there is a category of "collective conscience" shared by all employed in a given medical institution. This interpretation of the rule is unacceptable because it contradicts the very idea of the conscience clause (Zielińska, 2008, p. 561; Boratyńska, 2008).

9 In these laws, the centuries-old rule is hidden: "Salus aegroti suprema lex esto". 


\section{COMPULSORY SERVICES - ANALYSIS OF ARTICLE 30}

In practice, the medical profession is divided into compulsory and non-compulsory health care, medical and non-medical services. Compulsory medical care must be taken in emergency situations when the patient's health and life is compromised. Under such circumstances, the doctor cannot give up medical treatment, since any delay in action can result in death of the patient.

Information on this topic can be found in Article 30 of the Act on the Professions of Doctor and Dentist. It states as follows:

The doctor is obliged to give medical attention whenever a delay in delivery could result in the risk of loss of life, serious injury or severe discomfort, and in other cases of urgency (Article 30 of the Act on the Professions of Doctor and Dentist of 5 December 1996).

It is apparent from the wording of the law that a physician cannot rely on conscience clauses if there is a danger of losing the patient's health or life. A medical professional is obliged, according to the ethos of the medical profession, to provide immediate medical attention to the patient.

The same situation applies to the doctor's participation in compulsory, nonmedical services. A good example is referral for additional diagnostic tests. The medical staff should do this even more if there is a suspicion of genetic defect in the fetus. The purpose of prenatal testing is to detect early fetal disease and to take medicinal action. I consider applying the conscience clause in this situation to be unethical and illegal.

Doctors who argue that prenatal testing will allow a woman to decide to remove pregnancy are mistaken. One should not foresee events. Participation in diagnostic testing does not necessarily have anything to do with abortion decisions. Nevertheless, a pregnant woman, according to Article 4a of the Act on Family Planning, Protection of the Human Fetus and Conditions for Permissibility of Abortion, can request it.

According to this document, abortions are possible if permanent and irreversible genetic defects are detected (Article 4a of the Act on Family Planning, Protection of the Human Fetus and Conditions for Permissibility of Abortion, 1993) ${ }^{10}$.

10 "Abortion can only be performed by a doctor if: 1 . Pregnancy is a threat to the life or health of a pregnant woman; 2. Prenatal or other medical indications indicate a high probability of severe and irreversible fetal impairment or an incurable disease infecting his or her life; 3 . There is unreasonable suspicion that pregnancy was caused by a forbidden act”. 
Using the term "permissibility of abortion" suggests that a woman may decide to have an abortion but does not have to. In other words, no one has the right to impose their own convictions and make another decision. It is even more unlawful and against the right to freedom of belief to declare that doctors who are opposed to abortion have the right to believe not only this medical practice to be unethical, but also consent to any kind of examination that may lead to this goal.

I remind you that a medical professional cannot deprive patients of their rights. It can neither impose personal convictions nor lie to the patient, for example, not telling the truth about genetic defects or possible complications of pregnancy. Moral liability obliges medical staff to perform all the necessary research and respect the decisions of their patients.

\section{NOTIFYING THE PATIENT OF A MEDICAL ABSTENTION}

In everyday medical practice, respect for a patient is expressed by basic ethical principles, including: "Primum non nocere" and "salus aegroti suprema lex esto" (Code of Ethics for Medical Practices, 2004). These rules also appear in the Code of Ethics. Their purpose is to remind that the work done by a doctor is not merely providing medical services, it is also a vocation. The good of the patient, the concern for their health and life, are the most important values, therefore the physician should not take actions that may harm the other person.

One example that raises doubts is the adjournment of a patient's notification of failure to perform a particular medical activity.

If the reasons for resignation are religious motives, such as a doctor's unwillingness to perform an abortion, then in a situation analogous to the content of Article 4a of the Act on Family Planning, Protection of the Human Fetus and Conditions for Permissibility of Abortion the patient has the right to expect the doctor to be honest and to inform her of the possible denial in good time.

In fact, a pregnant woman does not always receive this information in due time. Some doctors believe that the choice of conscience clause solves the problem of their participation in the procedure. However, withdrawal from medical treatment cannot relate to the dismissal of the physician from moral responsibility for the care of the patient. The doctor cannot leave their charge without help. Just as they cannot abuse their rights and use jurisdiction to defend their own interests.

According to internal regulations, the patient should know about the refusal. Unfortunately, Article 39 of the Act on the Professions of Doctor and Dentist lacks accurate data. We do not know when a medical practitioner should notify his or 
her patient about resignation - if it should be done after collecting the appropriate medical records, or perhaps during one of the first visits?

The lack of specific indications gives rise to ambiguity, and they are the cause of future conflicts between the doctor and the patient.

Proponents of the conscience clause believe that this problem should be resolved ex officio. In other words, not a physician but a health care provider should be responsible for not informing the patient about the resignation. Information about the decision would be presented within two weeks of the letter being issued. Opponents of the conscience clause argue, however, that the duty of the treating physician is to perform the procedure regardless of one's own beliefs. Nevertheless, at the time of using the conscience clause, the physician should notify the patient. Any delay in this matter makes the abortion procedure illegal, and such treatment may induce a woman to seek medical services from non-categorized persons and in non-sterile conditions.

The arguments of both parties seem to be clear and factual. Unfortunately, in the presented ways of solving the problem, ambiguities are hidden. One of them concerns the referral of moral and legal responsibility from the doctor to the hospital. If it were to be considered that a healthcare facility could be liable for a medical failure by a medical practitioner, it would be very likely that the hospital management would be able to demand the adoption of workers with a specific worldview. The reason for the introduction of "collective conscience" would be the desire to reduce the lawsuits of doctors - gynecologists. Such a solution (as I wrote before) is incompatible with the jurisdiction, so it should be abandoned. The second concern is the transfer of responsibility from the institution to the doctor. While a medical professional has the right to object to a particular medical practice, he or she must, in good time, notify his or her patient's about the refusal. Some people think that the best solution to this problem is to enter a register of medical specialists. Each patient could choose the right doctor for their beliefs. Conflict between the two parties would be unlikely, because public disclosure of their views would make it possible to select patients with a similar worldview. I also find this argument imprecise. Not every doctor must agree to disclose his or her beliefs. The right to freedom of conscience actually offers you the opportunity to present your own views, but it is not an order. The task of the jurisdiction of the rule of law is primarily to protect the freedom of conscience and not to oblige health care workers to disclose personal beliefs.

In my opinion, the first proposal is closer to the solution of the problem. The task of health care should be to issue a statement and to inform the patient in due time of the refusal of the doctor. Medical staff should also be able to give their 
opinion to patients. Suggesting refusal in a timely manner would help the person to save time and nerves. Nevertheless, it must be borne in mind that the authorities cannot apply any repression to employees who use the conscience clause. I remind you that the category of "collective conscience" is incompatible with the principles of medical ethics and medical law.

\section{INDICATION OF THE DOCTOR WHO WILL PERFORM THE MEDICAL TREATMENT}

According to Article 39 of the Act on the Profession of Doctor and Dentist, in the event of non-performance of medical activities, the physician should indicate another doctor or therapist who will perform the procedure. The problem is not only that the doctor would appoint another person, but that the right to an employee's views would be the subject of public debate. As a result of the introduction of this rule, there might be some fear that some medical staff will insist on internal exclusion of their colleagues only because they have different beliefs than most employees. In this way, the management of hospitals would be relieved of the responsibility to inform patients about non-benefits, and the idea of creating medical institutions in which workers would present one worldview would become real.

This way of resolving the conflict is full of contradictions. On the one hand, every employee wants his or her rights to freedom of belief to be respected by other people; a provision is introduced that could lead to discrimination against employees on the grounds of worldview. On the other hand, although every human being has the right to private beliefs, it is a deceptive way of revealing them for the sake of the whole team. In both cases, employee rights are violated, so I believe that the doctor should not be required to appoint another doctor who will perform a specific health claim.

In one article, Nesterowicz and Karczewska-Kamińska argue that the editorial board of this provision (Article 39) is defective, the obligation should be charged to the establishment rather than the doctor (Nesterowicz \& Karczewska-Kamińska, 2014, p. 123).

I think the views of lawyers are correct. In their opinion, the content of this law is incompatible with the provisions of the Constitution of the Republic of Poland, Article 53 Section 1 and Article 53 Section 7 (The Constitution of the Republic of Poland, 1997). The duty of the doctor is not to perform administrative but health (medical and diagnostic) tasks. Caring for the health and well-being of the patient is paramount, and it should not be limited by any other activity. 
The remarks made by the lawyers are not related to the permission not to help the patient. If a physician decides to perform a specific medical activity and wishes to withdraw from it at the time of the treatment (Article 38 of the Act on the Professions of Doctor and Dentist), there is no legal consent.

The possibility of using the conscience clause only takes place if a doctor has not yet taken action, for example, to carry out an abortion. In such circumstances, he or she is obliged to notify the patient and report his or her decision to the supervisor.

Pointing out another doctor can lead to conflicts between employees. In addition, as Bosek believes, such an act directs the doctor to act as helper of the perpetrator of the act of wickedness (Bosek, 2014, p. 98). So there is a conviction that not only performing the act contrary to the conscience of the physician is unethical, but also the indication of the person who could carry out that treatment.

So what can be done to protect the rights of the doctor to freedom of conscience and respect the rights of the patient?

According to Article 12 of the Act on Patient's Rights and the Spokesman of Patient's Rights (2008), every treated person has the right to information about the type and scope of health care provided by the healthcare facility. Nevertheless, it cannot be inferred from the content of this law that hospitals have a strict mandate to provide all health services. Neither a public entity (hospital) nor a doctor have this obligation. In addition, the content of Article 39 does not specify the justification for the physician to refrain from providing health care (Bosek, 2014, p. 99), so it may be presumed to refer to a particular moral principle, in other words, the ethical standard in force in the Code of Ethics.

If doctors had the right to determine the scope of the health benefits (I mean voluntary benefits), and the information on that topic would be available to patients, then - I believe - it would respect the rights of both parties. This solution is only a proposition, but doctors would be able to make the decision to perform their work according to their own conscience, and patients might decide where to go for treatment and to choose a doctor, with the certainty that a particular medical service will be performed.

\section{NOTIFY THE SUPERVISOR OF YOUR RESIGNATION FROM THE MEDICAL SERVICE}

The last issue that raises doubts is informing your supervisor about non-performance. Should the doctor tell the head department about the resignation of each occupational activity? 
Failure to comply with the urgency of the health service is subject to legal sanctions, therefore the medical practitioner is responsible for all compulsory services. The physician has the right to refrain from performing the task but only in situations that do not endanger the health and life of the patient. In such circumstances, in accordance with the wording (Article 39, Paragraph 2 of the Act), the employee must notify the supervisor in writing.

Nevertheless, the disclosure of information about one's own beliefs raises a concern. According to the Constitution of the Republic of Poland (Article 53 (7)), a doctor is not obliged to do so. Here is the content of the document:

No one may be obliged by the public authorities to disclose their world views, religious beliefs or creeds (Article 53 Section 7 of the Constitution of the Republic of Poland, 1997).

The obligation to present private religious, political or philosophical views is forbidden. The supervisor cannot expect knowledge on these views from their own subordinates to be revealed. The personal beliefs of employees cannot be considered publicly, and hospital directors should be careful not to offer job to candidates with similar backgrounds. Only medical knowledge and competences are a fair assessment and have a major impact on getting a job.

Freedom of conscience does not only mean the right to self-opinion, but it is the right to act according to one's own conscience. Such freedom of belief not only offers health care professionals the right to have their own health care but, above all, to perform professional activities in accordance with their own beliefs, and this right cannot be taken away (by anybody).

\section{CONCLUSION}

At the beginning of the discussion I asked whether the clause of conscience should have its record in law. Although very often I hear a negative opinion, my thinking is different. I believe that every person should not only have the opportunity to make judgments consistent with their private opinion, but also demand the power of the state to protect the freedom of conscience. If different researchers (ethicists, lawyers, doctors) assume that everyone has the right to freedom of belief, regardless of profession, sex, place of residence and other factors, conscience is an innate category on which humanity depends. It is an evaluation-normative court, which suggests ways to solve any difficulties. The more we care about our own morality, the more decisions we make are prudent. 
Moral liability is often expressed by respect for others. If a doctor performs his or her professional duties in accordance with his or her conscience and knowledge of ethical and legal standards, he or she will be able to cope with any disputes before they occur. Such skill is valuable and should be taught in ethics classes. Every experienced doctor appreciates it. He or she knows that not only is knowledge useful in the medical profession, but also the ability to explain health problems and solve professional difficulties that often arise as a result of misunderstandings or conflicting expectations between the doctor and the patient. It is important to work on oneself - one's weaknesses, impatient temperament, and, above all, approach to one's own profession - to avoid conflict. The job of a doctor, nurse or midwife is primarily a vocation, not just a service. This advice is worth remembering because it allows us to understand that in this work, the most important concern is human.

\section{References}

Act on the Family Planning, Protection of the Human Fetus and Conditions for Permissibility of Abortion (1993). Retrieved from: http://isap.sejm.gov.pl/DetailsServlet?id=WDU199 30170078.

Act on Patient's Rights and the Spokesman of Patient's Rights (2008). Retrieved from: http:// isap.sejm.gov.pl/DetailsServlet?id=WDU20090520417.

Act on the Professions of Doctor and Dentist (1996). Retrieved from: http://isap.sejm.gov. $\mathrm{pl} /$ DetailsServlet?id=WDU19970280152.

Act on the Professions of Nurses and Midwives (2011). Retrieved from: http://isap.sejm.gov. pl/DetailsServlet?id=WDU20111741039.

Beauchamp, T.L., \& Childress, J.F. (1996). Zasady etyki medycznej. Warszawa: Książka i Wiedza.

Boratyńska, M. (2008). O łamaniu przepisów dopuszczających przerywanie ciąży. Prawo i Medycyna, 10(2), pp. 88-103.

Bosek, L. (2014). Problem zakresowej niekonstytucyjności art. 39 ustawy o zawodach lekarza i lekarza dentysty. In: P. Stanisz, J. Pawlikowski, \& M. Ordon (Eds.), Sprzeciw sumienia w praktyce medycznej - aspekty etyczne i prawne (pp. 87-104). Lublin: KUL.

Code of Ethics for Medical Practices (2004). Retrieved from: http://www.nil.org.pl/__data/ assets/pdf_file/0003/4764/Kodeks-Etyki-Lekarskiej.pdf.

Czekajewska, J. (2016). Szacunek dla autonomii kobiety ciężarnej a wolność sumienia lekarza. Etyczne konsekwencje odmowy wykonania świadczeń zdrowotnych przez pracowników służby zdrowia. Kultura i Edukacja, 3, pp. 33-46.

Galewicz, W. (2012). Jak rozumieć medyczną klauzulę sumienia? Diametros, 34, pp. 136-153. DOI: 10.13153/diam.34.2012.503.

Nawrot, O. (2014). Prawa człowieka, sprzeciw sumienia i państwo prawa. In: P. Stanisz, J. Pawlikowski, \& M. Ordon (Eds.), Sprzeciw sumienia w praktyce medycznej - aspekty etyczne i prawne (pp. 105-116). Lublin: KUL. 
Nesterowicz, M., \& Karczewska-Kamińska, N. (2014). Prawa pacjenta w kontekście odmowy udzielenia świadczeń medycznych przez lekarza lub szpital (w związku z klauzulą sumienia). In: P. Stanisz, J. Pawlikowski, \& M. Ordon (Eds.), Sprzeciw sumienia w praktyce medycznej - aspekty etyczne i prawne (pp. 117-130). Lublin: KUL.

Resolution 1763 on the Right to Conscientious Objection in Lawful Medical Care (2010). Retrieved from: http://www.assembly.coe.int/nw/xml/News/FeaturesManager-ViewEN.asp?ID=950.

The Constitution of the Republic of Poland (1997). Retrieved from: http://www.sejm.gov.pl/ prawo/konst/angielski/kon1.htm.

The European Convention on Human Rights (1950). Retrieved from: https://www.echr.coe. int/Documents/Convention_ENG.pdf.

The International Covenant on Civil and Political Rights (1966). Retrieved from: https://www. ohchr.org/EN/ProfessionalInterest/Pages/CCPR.aspx.

The Position of the Committee of Bioethics at the Presidium of the Polish Academy of Sciences No. 4/2013 of 12 November 2013 on the conscience clause. Retrieved from: http:// bioetyka.pan.pl/index.php/stage-a-opin-community-of--50-200/110-position-bioethicscommittee-at-presidency-pan-nr-4-2013-from-12-November-2013-year-on-so-clauseconscience.

The Universal Declaration of Human Rights (1948). Retrieved from: http://www.un.org/en/ga/ search/view_doc.asp?symbol=A/RES/217(III).

Zielińska, E. (2008). Ustawa o zawodach lekarza i lekarza dentysty. Commentary. In: E. Zielińska (Ed.), (p. 561). Warszawa: ABC-Wolters Kluwer Business.

Zoll, A. (2014). Klauzula sumienia. In: P. Stanisz, J. Pawlikowski, \& M. Ordon (Eds.), Sprzeciw sumienia w praktyce medycznej - aspekty etyczne i prawne (pp. 77-86). Lublin: KUL. 